\title{
Some GCM Experiments of the Asian Summer Monsoon Related to Land Boundary Conditions
}

\author{
by \\ Dodla V. Bhaskar Rao*, Koji Yamazaki and Akio Kitoh \\ Meteorological Research Institute, Tsukuba, Ibaraki, 305 Japan
}

(Received May 7, 1991; Revised September 26, 1991)

\begin{abstract}
The results of a 20-year simulation (control run) by the 5-layer MRI AGCM are analyzed for the Asian monsoon region for the summer season (June-September) and are compared with the observations. Overall large-scale features are simulated with considerable reality, though there are drawbacks such as a weak monsoon flow. Motivated by these drawbacks, some numerical experiments related to land-surface boundary conditions are performed. The cold bias in the low-level atmosphere over the Arabian peninsula found in the control run is alleviated by replacing swamp grid points of the Persian Gulf and the Red Sea with land points. The underestimated precipitation at the foothills of the Himalayas is alleviated to some extent by forcing ground to be wet over the Indian subcontinent. These experiments show the importance of land-surface processes for regional climate. However, the improvements in the above simulations are limited in regional scale and large-scale errors are not alleviated significantly. The simulation with worldwide elevated topography shows the significant weakening of the monsoon circulation, though regional-scale features show an improvement. This fact shows that the use of excessively high mountains deteriorates the simulation of the Asian summer monsoon circulation.
\end{abstract}

\section{Introduction}

The Asian summer monsoon circulation is an important component of the tropical circulation and the reversal of the wind regime from the northeast tradewind flow during winter to the southwesterly flow during summer is a unique feature in the global circulation. The reason for this reversal is the differential heating between the large Asiatic land mass and the surrounding oceans. Attempts are

\section{* Permanent affiliation: Department of Meteorolo- gy and Oceanography, Andhra University, Visakhapatnam, 53003 India}

(C) 1991 by the Meteorological Research Institute continuously made to study different aspects of the summer monsoon and to understand their mechanisms and physical processes. Numerical models of the atmospheric general circulation are used to simulate the global circulation and to make controlled experiments to understand the changes in atmospheric circulation and climate. In the past several numerical experiments have been conducted by different modelling groups with their GCMs to study some aspects of the Asian summer monsoon (Hahn and Manabe, 1975 ; Shukla, 1975 ; Washington et al., 1977; Gilchrist, 1977, 1981; Sud and Smith, 1985 ; Krishnamurti, 1987 ; Yamazaki, 1988; Tibaldi et al., 1990). There are also active monsoon climate researches in numbers 
of institutes and universities in association with the TOGA Monsoon Numerical Experimentation Group (MONEG) (WMO, 1990).

As a part of the studies on the atmospheric general circulation at the Meteorological Research Institute (MRI), two numerical experiments have been performed in which the MRI Atmospheric General Circulation Model (MRI AGCM) has been integrated for a 20 -year period using the climatological sea surface temperature (SST) values and the real SST values (Kitoh, 1991). It has been reported that the MRI AGCM has been successful in simulating many observed features of the atmospheric circulation of which the Asian monsoon circulation forms an integrated part (Tokioka et al., 1985 ; Kitoh and Tokioka, 1986, 1987). However, there remain some shortcomings in the simulation such as a weak monsoon flow compared with the observation. In the present study, the results from the MRI AGCM integrations are reexamined for the Asian region for the summer monsoon season (i.e. June -September). Then some numerical experiments are carried out with a view to studying the changes in the Asian summer monsoon circulation in response to different boundary conditions specified for each experiment. These sensitivity experiments are motivated to alleviate the model's bias. In section 2 a brief description of the MRI AGCM and the design of the numerical experiments is given. In section $3 a$ brief summary of the observational aspects and results from the MRI AGCM integrations with the climatological SST (hereafter referred to as the control run) followed by the description of the results from the sensitivity experiments are given. Finally a summary of the results and discussion of them are presented in section 4 .

\section{The numerical model and experiments}

The model used for this study is a 5-layer atmospheric general circulation model. The model is of grid representation with a horizontal resolution of $4^{\circ}$ latitude and $5^{\circ}$ longitude with its top at $100 \mathrm{hPa}$. Physical processes included are the parameterization of cumulus convection, planetary boundary layer (PBL), radiation interactive with model-generated cloud. Ground hydrology is a bucket model and predicts snow mass and soil moisture. In the bucket model, field capacity is a function of latitude with a large value in the tropics ( $15 \mathrm{~g}$ $\mathrm{cm}^{-2}$ at the equator) and a small value in high latitudes $\left(3 \mathrm{~g} \mathrm{~cm}^{-2}\right.$ poleward of $60^{\circ}$ latitude). Diurnal as well as seasonal variations of insolation are included. The effect of the subgrid scale topography is incorporated by increasing surface drag coefficients over land as a function of the direction-dependent sub-grid scale topography (a silhouette mountain, see Kitoh and Yamazaki, 1991). The model is the same as the one used in Kitoh (1991).

The control run has been integrated for 20 years using the climatological SST. From the results we can obtain statistics of the model's climate and the standard deviations, which are utilized to assess the statistical significance of other sensitivity experiments. In addition to reanalysis of the control run, some sensitivity experiments are performed. In these experiments, integrations are performed starting from the initial condition of 1st April of the first year in the control run till the end of September and the mean patterns for the four month period from June to September are analyzed.

The first experiment is the "No Persian Gulf and Red Sea (NPG) experiment". In this experiment three "swamp" grid points corresponding to the Persian Gulf and the Red Sea are replaced with land grid points (see Fig. 1). The "swamp" means that soil moisture is kept saturated and the ground temperature is calculated in the same manner as in the land grid point. As a supplement to the NPG experiment, another run is performed where these three swamp grid points are replaced with ocean grid points. In the second experiment, the topography at each grid point is set to be the maximum value of the topography in the grid box of $4^{\circ}$ latitude and $5^{\circ}$ longitude based on $1^{\circ}$ $\times 1^{\circ}$ topography data. The modification is made worldwide and this experiment is referred to as the "High Mountain (MTN) experiment". The topography used in the MTN experiment as well as that in the control 

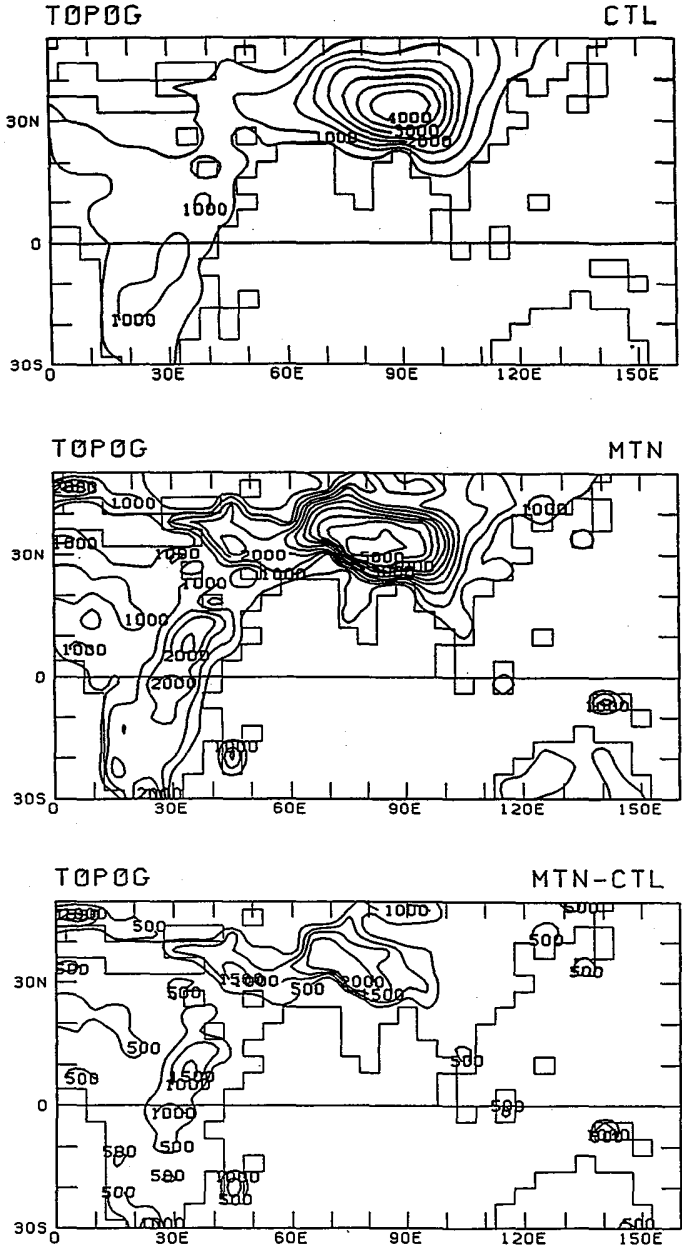

Fig. 1 Top: topography used in the standard MRI GCM.

Middle: topography used in the "MTN" experiment.

Bottom: Difference of topography between "MTN" model and the standard model. Contour intervals are $500 \mathrm{~m}$ in all panels.

run and the difference are shown in Fig. 1. In the third experiment, the soil moisture of the Indian subcontinent $\left(2^{\circ}-30^{\circ} \mathrm{N}, 72^{\circ}-90^{\circ} \mathrm{E}\right)$ is kept saturated throughout the integration period. This experiment is hereafter called the "Wet India (WET) experiment". A supplementary experiment to the WET experiment is also performed. In this experiment, the soil mois- ture of the Indian subcontinent is made saturated at the initial starting time (1st of April) and allowed to vary during the integration.

\section{Results}

In this section a brief summary of the observations and the results from the control run is given followed by the description of the results from the sensitivity experiments conducted with different boundary conditions. Though the analyses are available for the entire globe, results are presented only for the region between $30^{\circ} \mathrm{S}-50^{\circ} \mathrm{N}$ and $0^{\circ}-160^{\circ} \mathrm{E}$ that covers the region of the Asian summer monsoon circulation. The mean patterns for the four month period from June to September are presented. The results of the sensitivity experiments are described in comparison with the results from the control run; results similar to the control run are not mentioned.

\section{a. Observed features}

Top panels of Figs. 2 through 9 show observed fields over the Indian summer monsoon region. Except for the precipitation map, the observations are based on U.S. NMC (National Meteorological Center) 9-year mean data during the period from 1979 through 1987. The precipitation map is made using the data by Jaeger (1976).

The salient features of the observed Asian summer monsoon circulation are summarized as follows.

(i) At $850 \mathrm{hPa}$ a cross equatorial flow from the Southern Hemisphere results in the monsoon westerly flow reaching its strength of $15 \mathrm{~m} \mathrm{~s}^{-1}$ over the Arabian sea and $10 \mathrm{~m} \mathrm{~s}^{-1}$ over the Bay of Bengal (Fig. 2). The flow has a cyclonic curvature over South India with a northwesterly component over the Arabian Sea and a southwesterly component over the Bay of Bengal. The monsoon flow converges into the monsoon trough, which extends from the head of the Bay of Bengal northwest towards the Arabian peninsula, around which light variable winds prevail with cyclonic vorticity. 

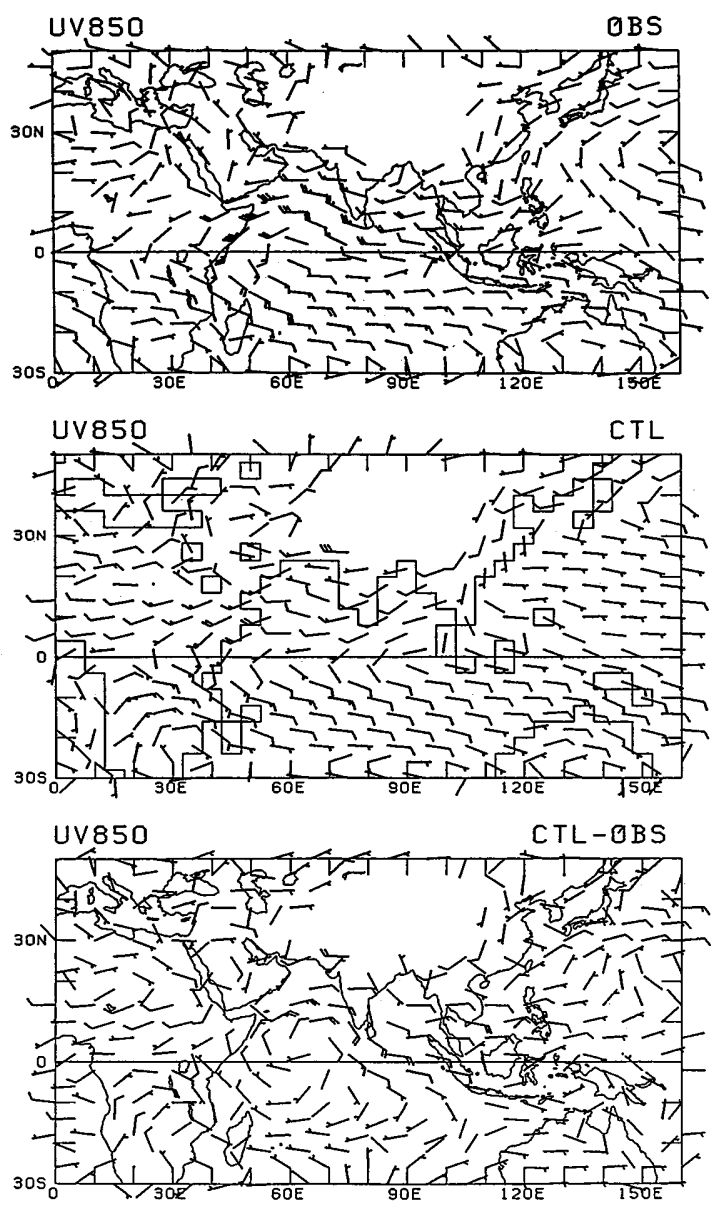

Fig. 2 Four month mean (June-September) wind fields at $850 \mathrm{hPa}$. Arrows are drawn with weather chart convention and the unit is knot $\left(1 \mathrm{~m} \mathrm{~s}^{-1}=1.94 \mathrm{knot}\right)$. A full bar denotes 10 knots, a half bar 5 knots. A closed triangle denotes 50 knots (not present in this figure). Arrows are not drawn over regions where the elevation is more than $1500 \mathrm{~m}$. Top : observation based on 9 year (1979-87) statistics of U.S. NMC analysis. Middle : control (CTL) run. Bottom : control run-observation.

(ii) At $200 \mathrm{hPa}$ an anticyclone (the Tibetan high) exists around $30^{\circ} \mathrm{N}$ over the Tibetan plateau (Fig. 3). Westerlies with a jet maximum of $30 \mathrm{~m} \mathrm{~s}^{-1}$ are observed to the north of the anticyclone, extending east towards northern Japan. To the south of
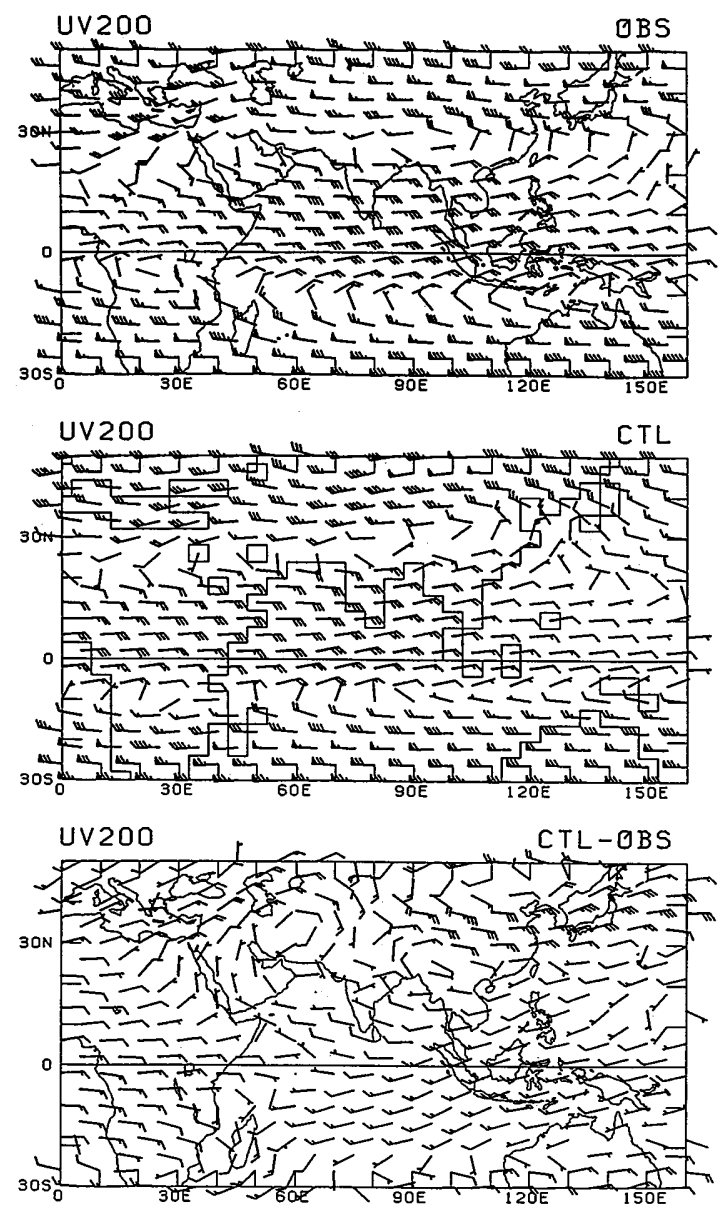

Fig. 3 Same as in Fig. 2 except for wind fields at $200 \mathrm{hPa}$.

the Tibetan high, the tropical easterly jet with a strength of $20 \mathrm{~m} \mathrm{~s}^{-1}$ is located at about $5^{\circ}-15^{\circ} \mathrm{N}$.

(iii) A warm region exists over the Arabian peninsula extending to northwest India at $850 \mathrm{hPa}$ (Fig. 4). It is noted that at the lower levels the temperature over the Arabian peninsula is by far the highest, exceeding that over Sahara by more than 5 ${ }^{\circ} \mathrm{C}$. At $200 \mathrm{hPa}$ a warm region is located over the Tibetan plateau coinciding with the anticyclone at this level (Fig. 5).

(iv) The sea level pressure pattern shows a low pressure area extending from the head of the Bay of Bengal towards northwest 

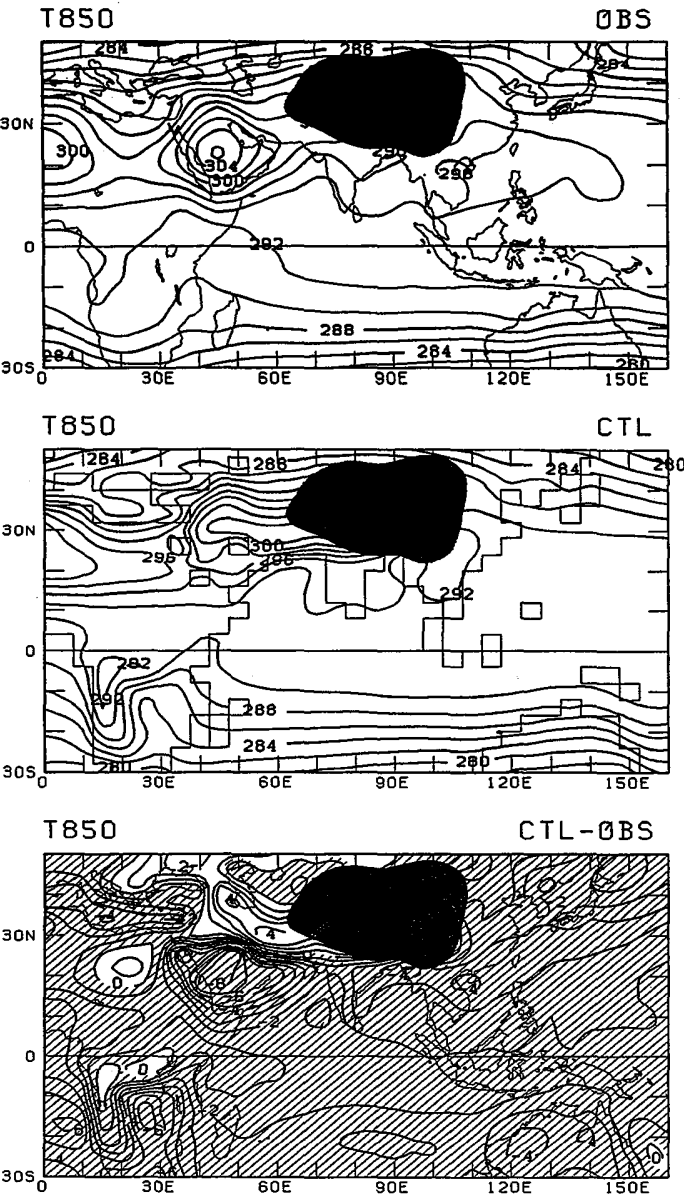

Fig. 4 Same as in Fig. 2 except for temperature fields at $850 \mathrm{hPa}$.

Contour intervals for top and middle panels are $2^{\circ} \mathrm{C}$. Contour intervals for bottom panel are $1^{\circ} \mathrm{C}$ and negative values are hatched.

India and the Arabian peninsula corresponding with the monsoon trough (Fig. 6).

( v) The height pattern at $200 \mathrm{hPa}$ shows a ridge over India extending east-west along $25^{\circ} \mathrm{N}$ (Fig. 7), while at $500 \mathrm{hPa}$ a trough protrudes over the Indian subcontinent from middle latitudes, suggesting a strong baroclinic stratification (Fig. 8).

(vi) The precipitation distribution shows concentrations over the west coast of India, near the equator and the Indochina peninsula through northeast India along the
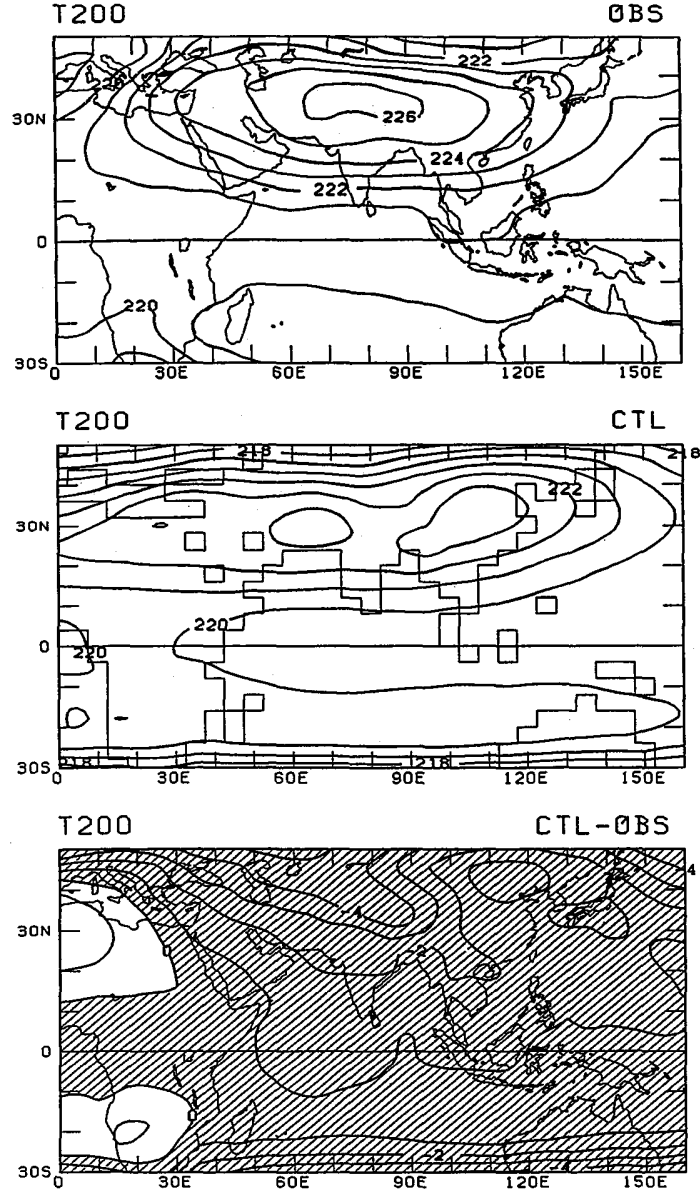

Fig. 5 Same as in Fig. 2 except for temperature fields at $200 \mathrm{hPa}$. Contour intervals are 1 ${ }^{\circ} \mathrm{C}$ in all panels.

foothills of the Himalayas that indicate the influence of orography (Fig. 9).

b. Results of the control run

Middle panels of Figs. 2 through 9 show the mean fields of the control run and the bottom ones show the deviations from the observation. In this simulation many features of the Asian summer monsoon circulation are obtained.

The wind flow pattern at $850 \mathrm{hPa}$ clearly shows the cross equatorial flow and the 

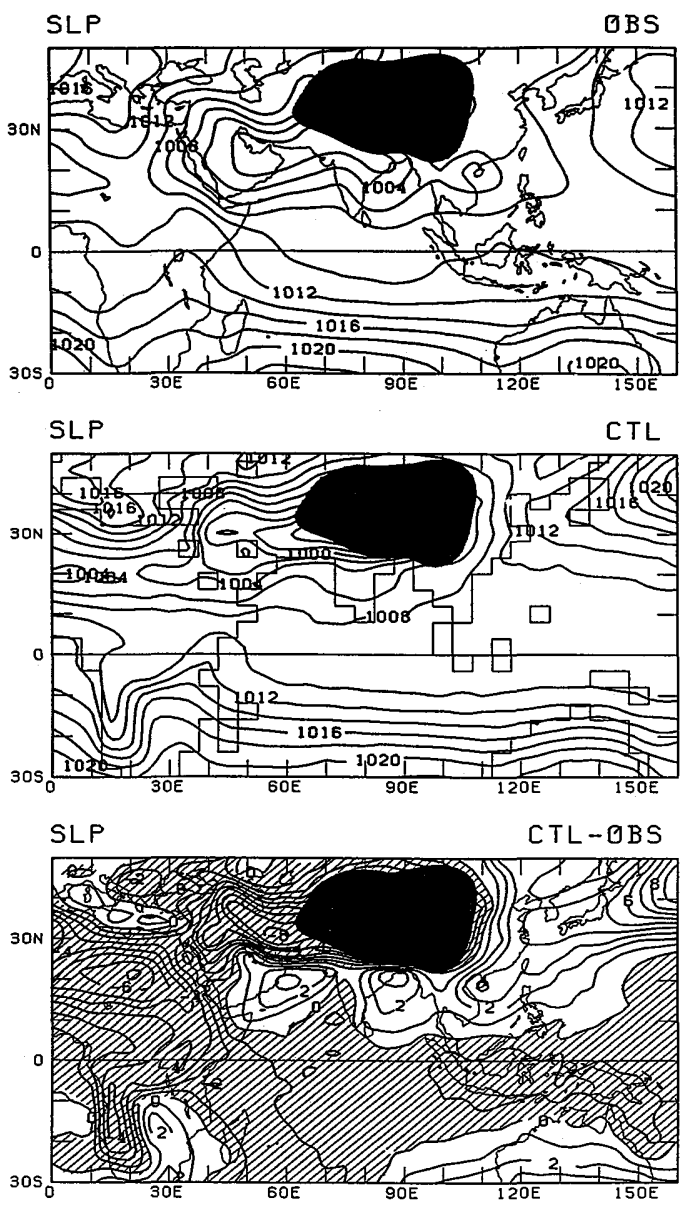

Fig. 6 Same as in Fig. 2 except for sea level pressure. Contour intervals for top and middle panels are $2 \mathrm{hPa}$. Contour intervals for bottom panel are $1 \mathrm{hPa}$ and negative values are hatched.

monsoon westerly flow. But the westerly flow over the Arabian sea is obtained with its strength of $5-8 \mathrm{~m} \mathrm{~s}^{-1}$ which is much less than the observed values of $10-15 \mathrm{~m} \mathrm{~s}^{-1}$ (Fig. 2). At $200 \mathrm{hPa}$ the strengths of both the westerly and easterly jet streams are less than those of the observed and the position of the westerly jet is slightly shifted northward in the simulation (Fig. 3). The position of the ridge at $30^{\circ} \mathrm{N}$ coincides with the observation. The anticyclonic circulation is stronger over north China and weaker over Persia compared with
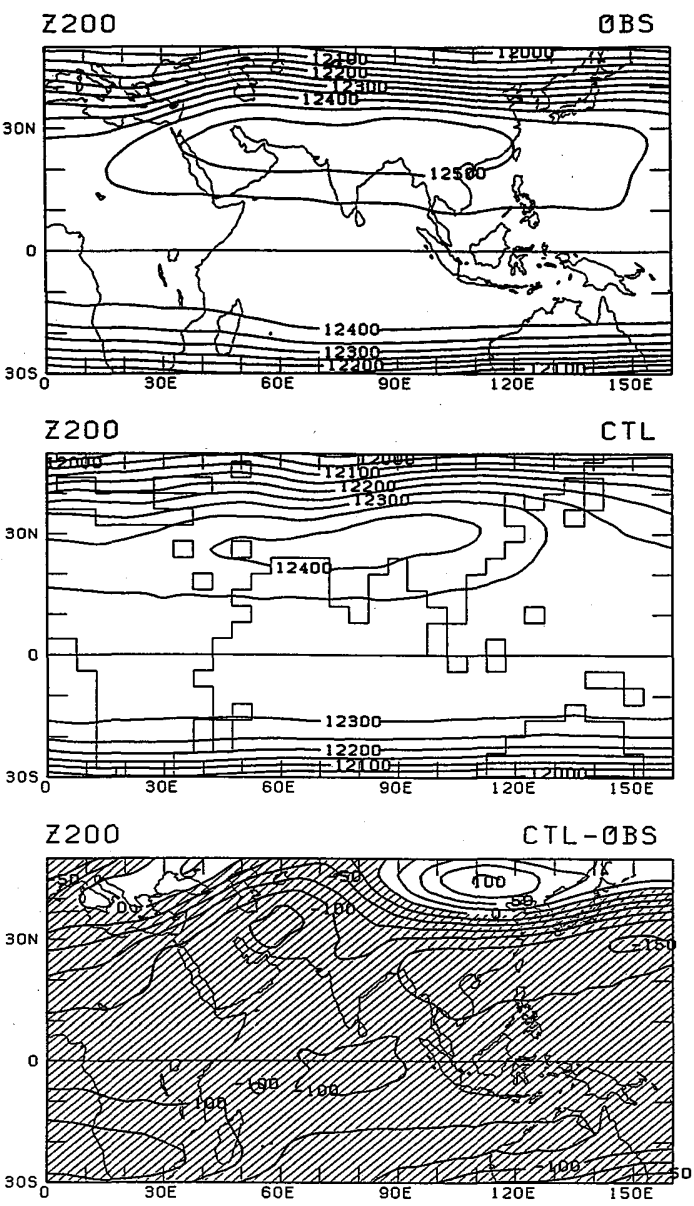

Fig. 7 Same as in Fig. 2 except for geopotential height fields at $200 \mathrm{hPa}$. Contour intervals for top and middle panels are 50 gpm. Contour intervals for bottom panel are $25 \mathrm{gpm}$ and negative values are hatched.

the observation.

The temperature field at $850 \mathrm{hPa}$ shows a high temperature belt over Persia but the observed magnitude of the warm core over Arabia is not obtained in the simulation (Fig. 4). The difference reaches as much as $-8^{\circ} \mathrm{C}$ there. This is also the case for the surface air temperature (not shown). It may be noted that the GCM simulations commonly underestimate the $850 \mathrm{hPa}$ temperatures by about $2^{\circ} \mathrm{C}$ (WMO, 1988 ; Gates et al., 1990 ; Boer et al., 1991) and the MRI AGCM also possesses this systematic 


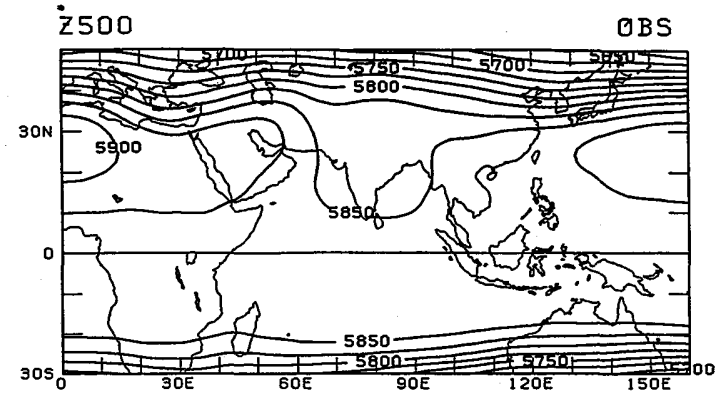

$Z 500$

CTL
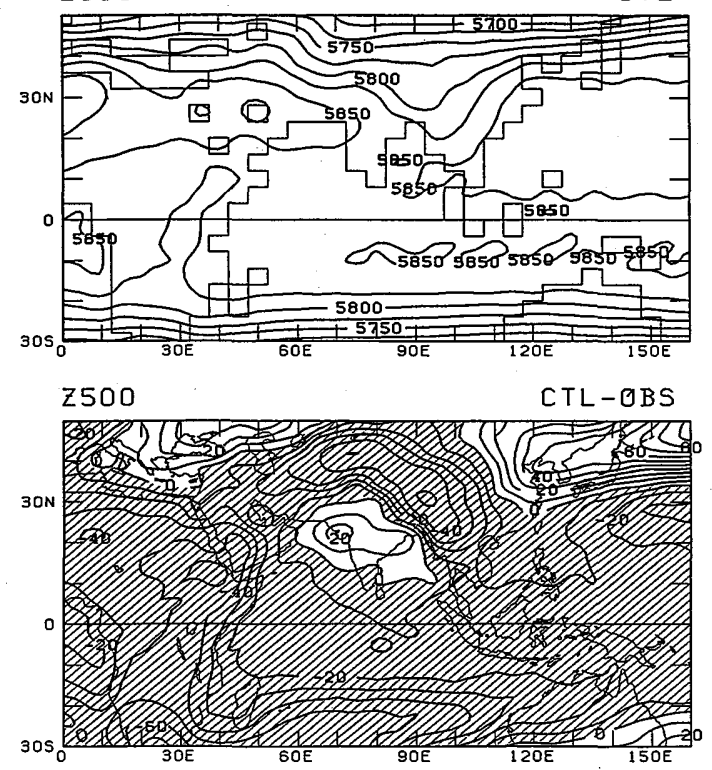

Fig. 8 Same as in Fig. 2 except for geopotential height fields at $500 \mathrm{hPa}$. Contour intervals for top and middle panels are 25 gpm. Contour intervals for the bottom are $10 \mathrm{gpm}$ and negative values are hatched.

bias. At $200 \mathrm{hPa}$ the temperature field shows a warm region extending east-west over Tibet and south China but the temperature values are less by $1-4^{\circ} \mathrm{C}$ compared with the observations, resulting in the decrease of the north-south temperature gradient in the simulation (Fig. 5). This conforms with the simulated wind field in which both the jet streams are weaker than the observed. It is also noted that the simulated temperature maxima at $200 \mathrm{hPa}$ are split into two regions and that there exists a local
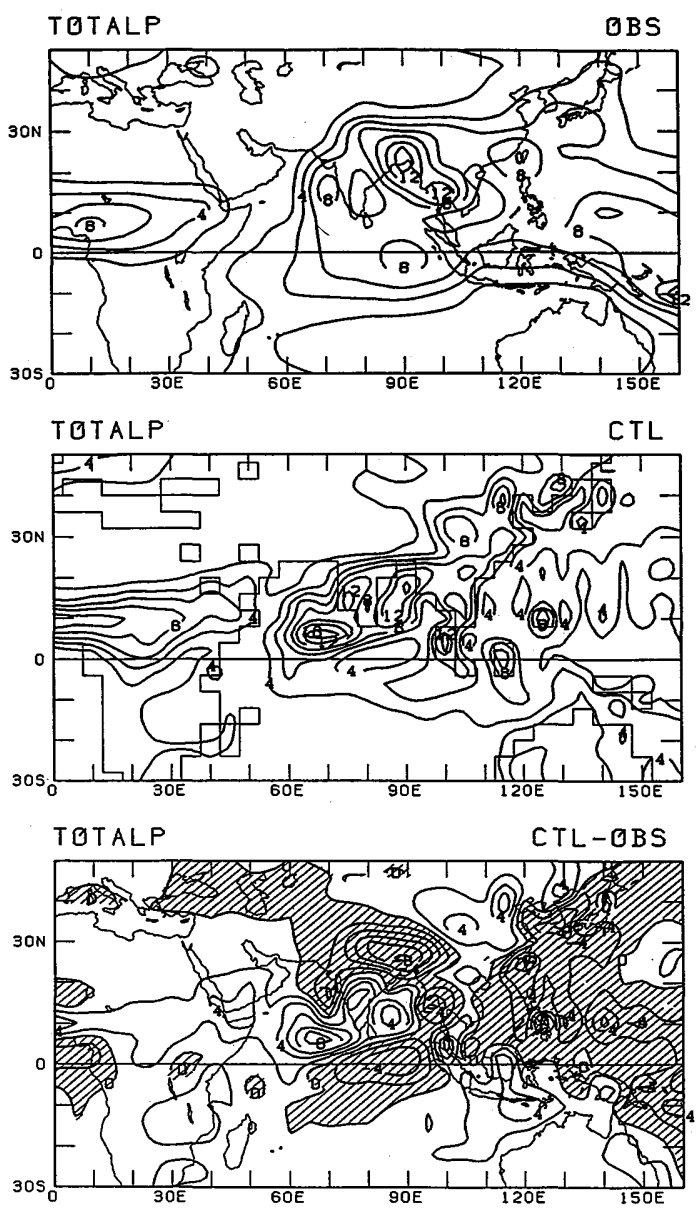

Fig. 9 Four month mean (June-September) precipitation. Unit is $\mathrm{mm} \mathrm{day}{ }^{-1}$. Top: observation based on Jaeger (1976). Middle: control (CTL) run.

Bottom : control run-observation. Contour intervals in all panels are $2 \mathrm{~mm}$ day $^{-1}$.

minimum over the Himalayas where the maximum temperature is observed. This may reflect the distorted distribution in precipitation in the model.

The sea level pressure distribution shows a low pressure region over Arabia and north India (Fig. 6). The monsoon trough over north India could not be clearly identified. The pressure gradient over the Arabian Sea is slightly weaker than the observation. At 200 $\mathrm{hPa}$, the Tibetan high is situated along $30^{\circ} \mathrm{N}$ 
with a slight east-northeast to west-southwest tilt, which is shifted northward compared with the observation (Fig. 7). Otherwise, contours agree well with the observation. The contour patterns at $500 \mathrm{hPa}$ show that the observed trough over the Indian subcontinent is positioned over Indo-China in the simulation (Fig. 8).

The precipitation pattern shows a maximum rainfall over the oceans and the west coast of India (Fig. 9). An intense rainfall occurrence over northeast India is not obtained in this experiment. The map of ground wetness reveals dryness over central and north India. The precipitation in the western Pacific region is generally less than observations. This less diabatic heating probably caused the $200 \mathrm{hPa}$ weak easterly jet over the Indian Ocean and the weak Tibetan high seen in Fig. 3 (Gill, 1980; Kuma, 1988).

\section{c. The No Persian Gulf and Red Sea (NPG) experiment}

As described in the previous sub-section, the lower tropospheric temperature over the Arabian peninsula is lower in the control run than the observation. One reason for this may be that due to the coarse horizontal resolution of $4^{\circ}$ in latitude and $5^{\circ}$ in longitude the representation of the Persian Gulf and the Red Sea as swamps affects the neighboring region in the computation of heating, leading to lower temperature values at the lower atmosphere. With a view to understanding this possibility a numerical experiment has been designed with the surface boundary condition that the Persian Gulf and the Red Sea are replaced with land mass with characteristics like those of the neighborhood.

Figure 10 shows that the temperature at $850 \mathrm{hPa}$ increased over the Arabian peninsula by about $4-5^{\circ} \mathrm{C}$ compared with the control run and so also the temperature gradient between the peninsula and the Arabian Sea. Asterisk (*) in the difference map indicates statistically significant points with $95 \%$ confidence level. The precipitation reduced over the Arabian peninsula and its southwest neighborhood (Fig. 11). The low-level atmosphere becomes dry in the NPG run over the Arabian peninsula. It is
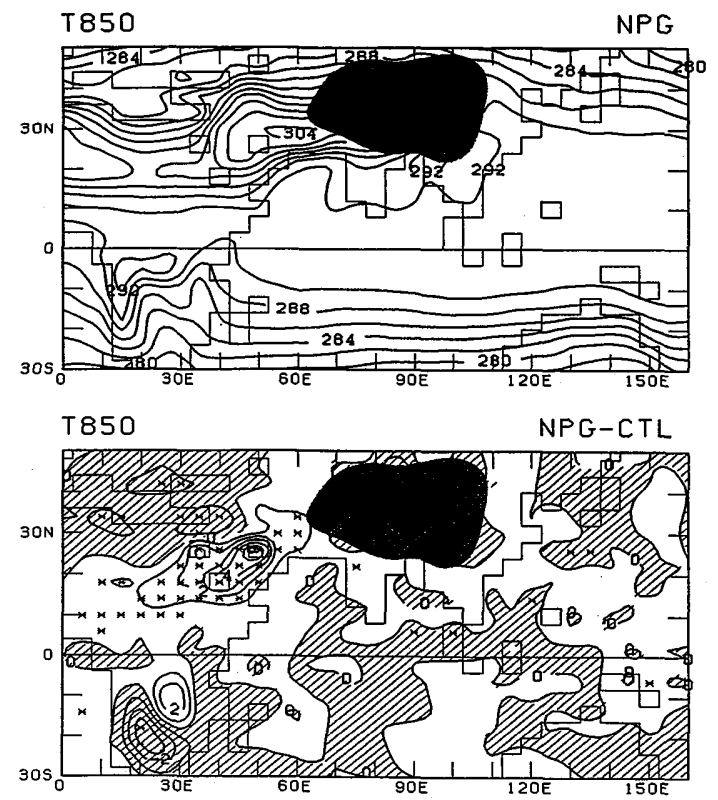

Fig. 10 Four month mean (June-September) temperature fields at $850 \mathrm{hPa}$. Top: "NPG" run. Bottom: "NPG" run - control run. Contour intervals for top panels are $2^{\circ} \mathrm{C}$. Contour intervals for bottom panel are $1^{\circ} \mathrm{C}$ and negative values are hatched.

Asterisk $(*)$ in the difference map indicates statistically significant points with $95 \%$ confidence level.

noted that the temperature increase is significant not only on three grid points where the surface conditions have been changed, but also over the broad region extending from the Sudan to Iran. This large-scale change results from temperature advection, reduced precipitation and reduced water vapor, and their positive feedback. This result implies the necessity of careful treatment of surface boundary conditions in simulating regional climate. The sea level pressure (figure not shown) decreased by 3 to $4 \mathrm{hPa}$ over Arabia and the wind flow patterns show a slight intensification of the cyclonic circulation over the Arabian peninsula at lower levels (Fig. 12), which increases the cyclonic bias. This seems to be a shortcoming of replacement of the swamp grid points with land grid points. At upper levels middle latitude 


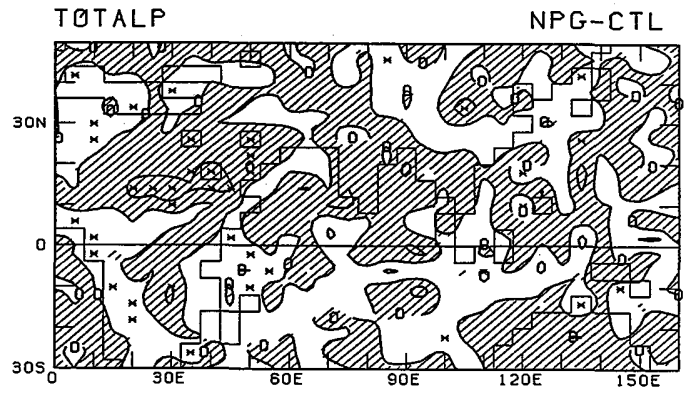

Fig. 11 Four month mean (June-September) precipitation for "NPG" run-control run. Contour intervals are $1 \mathrm{~mm}$ day $^{-1}$ and negative values are hatched. Asterisk $(*)$ indicates statistically significant points with $95 \%$ confidence level.

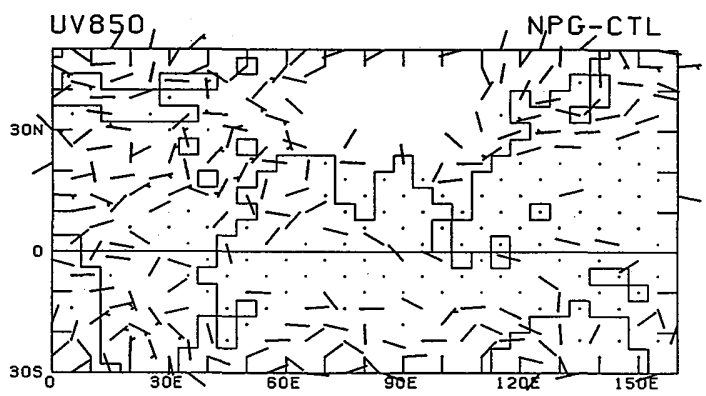

Fig. 12 Four month mean (June-September) wind fields at $850 \mathrm{hPa}$ for "NPG" run - control run. Arrows are drawn with weather chart convention and the unit is knot $\left(1 \mathrm{~m} \mathrm{~s}^{-1}=1.94\right.$ knot $)$.

westerlies have been strengthened over west Asia (figure not shown).

The contour pattern at $500 \mathrm{hPa}$ shows an increase in height over Arabia and Persia while it decreased over most of the other regions, especially over Turkey and Japan (Fig. 13). At $200 \mathrm{hPa}$ the difference pattern is similar to that at $500 \mathrm{hPa}$. The sea level pressure anomaly over Turkey is positive, showing a baroclinic character, whereas that over Japan is negative, indicating a barotropic character. These changes are towards the alleviation of systematic errors in the control run shown in the bottom panel of Fig. 8 . The change of geo-

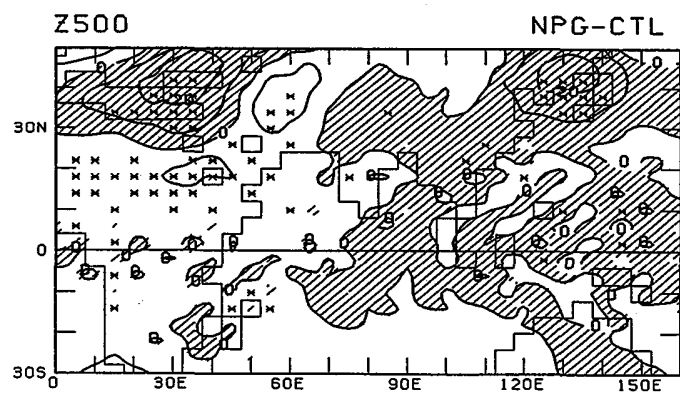

Fig. 13 Four month mean (June-September) geopotential height field at $500 \mathrm{hPa}$ for "NPG" run-control run. Contour intervals are $10 \mathrm{gpm}$ and negative values are hatched. Asterisk $(*)$ indicates statistically significant points with $95 \%$ confidence level.

potential height at middle and upper levels over Turkey is probably a baroclinic response to the reduction in convective heating over the Arabian peninsula through Sudan (Gill, 1980).

A supplementary experiment to the NPG run is also performed. In this experiment, three swamp grid points are replaced with ocean grid points. The results of this experiment are very similar to the control run and there is nothing special to mention.

\section{d. The High Mountain (MTN) experiment}

In this experiment the topography at each grid point is fixed at the maximum value of the topography in the grid box of $4^{\circ}$ in latitude and $5^{\circ}$ in longitude surrounding the point. The large differences in topography over $2000 \mathrm{~m}$ are found over the Himalayas and the Pamirs plateau (Fig. 1). The $500 \mathrm{hPa}$ level is well above the ground surface in the control experiment, whereas it is very close to the surface or below the ground in the MTN experiment over the Himalayas. Thus the elevated topography is expected to increase barrier effects in the lower and middle troposphere near mountains. The results from this experiment are as follows.

The wind flow pattern at $850 \mathrm{hPa}$ shows a reduction in the strength of the monsoon westerly flow over the entire region (Fig. 14). Small cyclonic eddies are noted in the monsoon 

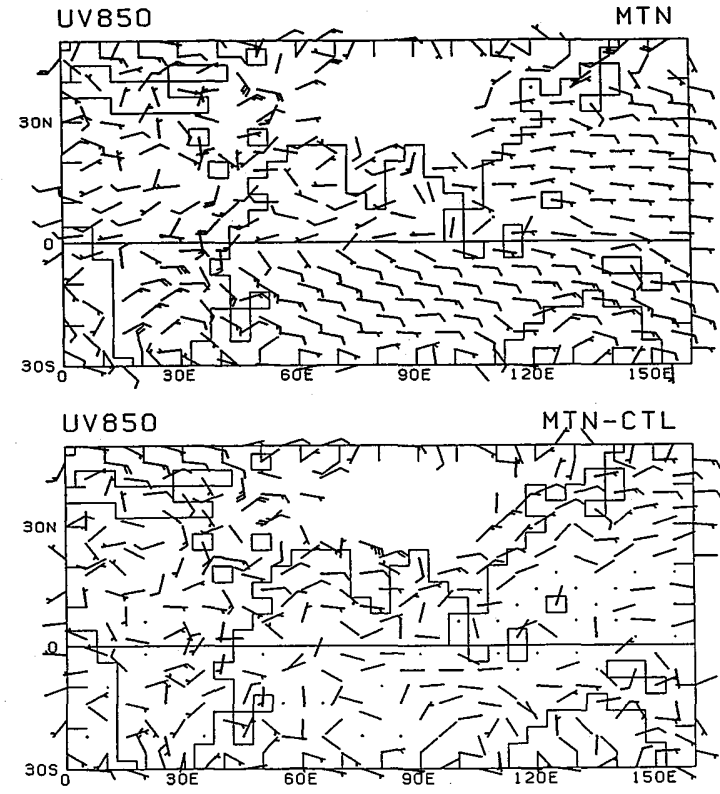

Fig. 14 Four month mean (June-September) wind fields at $850 \mathrm{hPa}$. Arrows are drawn with weather chart convention and the unit is knot $\left(1 \mathrm{~m} \mathrm{~s}^{-1}=1.94 \mathrm{knot}\right)$. Top: "MTN" run. Bottom: "MTN" run-control run.

trough region and along the west coast of India. An interesting aspect is the presence of the southerly flow near the head of the Bay of Bengal, which was not simulated in any of the other experiments performed in this study. The $200 \mathrm{hPa}$ flow pattern also indicates the weakening of the middle latitude westerlies and the ridge being replaced by a cyclonic circulation over Tibet (figure not shown). Two weak highs are found over China and Egypt. The intensity of the subtropical easterlies was extremely weakened in the MTN run. The high drag created by the increase of mountain topography, especially the Himalayas, has forced the reduction in the strength of the wind flow.

The temperatures at lower levels are reduced over the south Asian continent (figure not shown). To the north of the Himalayas, the temperatures at lower levels increase, resulting in a weakening of meridional temperature gradients around $40^{\circ} \mathrm{N}$. The low-level temper-
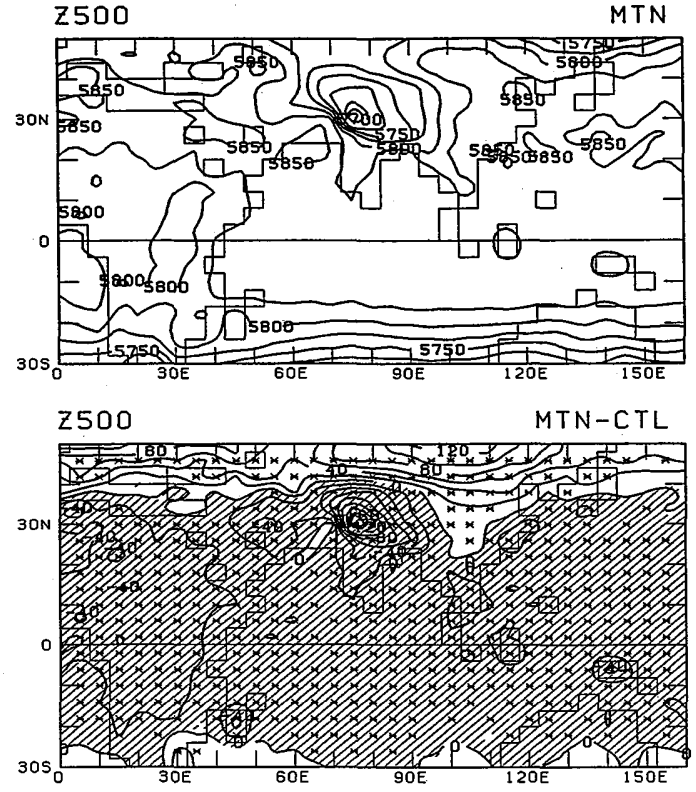

Fig. 15 Four month mean (June-September) geopotential height fields at $500 \mathrm{hPa}$. Top: "MTN" run. Bottom: "MTN" run-control run. Contour intervals for top panel are $25 \mathrm{gpm}$. Contour intervals for the bottom are $20 \mathrm{gpm}$ and negative values are hatched. Asterisk $(*)$ in the difference map indicates statistically significant points with $95 \%$ confidence level.

atures over the ocean do not change much, so that the land-ocean heat contrast is pronounced in northern midlatitudes. At higher levels, the pattern of temperature change is similar to that at lower levels. To the north of $40^{\circ} \mathrm{N}$ the temperature increases, while to the south of 40 ${ }^{\circ} \mathrm{N}$ it decreases, resulting in a very weak temperature gradient over the South Asia.

The geopotential height at $500 \mathrm{hPa}$ shows a decrease over Tibet along with the weakening of the subtropical ridges over the western Pacific and over north Africa (Fig. 15). To the north of $40^{\circ} \mathrm{N}$, the height generally increased and the westerly flow at midlatitudes was weakened. Similar changes were reported when an envelope orography was used in the ECMWF model (Jarraud et al., 1988). The large-scale pattern at this level is quite different 


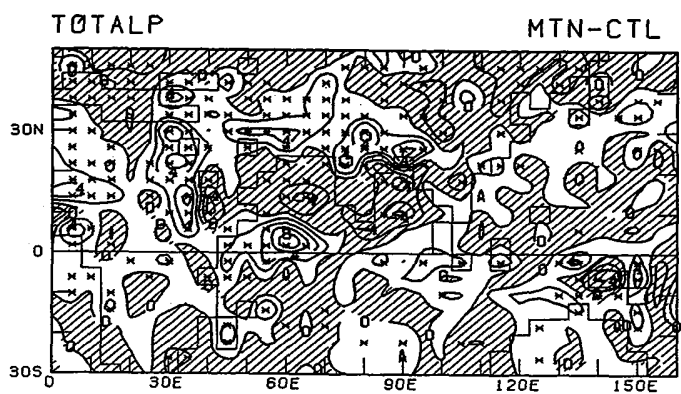

Fig. 16 Four month mean (June-September) precipitation for "MTN" run-control run. Contour intervals are $2 \mathrm{~mm} \mathrm{day}^{-1}$ and negative values are hatched. Asterisk $(*)$ indicates statistically significant points with $95 \%$ confidence level.

from both the observation and the control run (see Fig. 8). However it shows a westward shift of the trough to over the Indian subcontinent, which is nearer to the observation. The $200 \mathrm{hPa}$ contour height field shows a break of the anticyclone over Tibet resulting in a weak cyclonic circulation (figure not shown). The sea level pressure field shows a deep low pressure area over northwest India extending over to Persia (figure not shown). This feature is close to the observations compared with the other experiments. The sea level pressure over Eurasia increases and the north Pacific subtropical high is enhanced. Slingo and Pearson (1987) showed that the use of envelope orog. raphy exaggerates the intensities of both the northern hemisphere continental lows and oceanic highs due to the too pronounced thermal forcing on the elevated land surface during summer. In the MTN run, a similar tendency appeared except for the intensification of continental lows.

The total precipitation pattern shows an increase of precipitation and a northward shift over the Bay of Bengal and the Indian subcontinent (Fig. 16). It also shows a decrease over the Arabian Sea and an increase over the equatorial western Indian Ocean. Figure 17 shows "precipitation minus evaporation," which is equal to total moisture convergence,
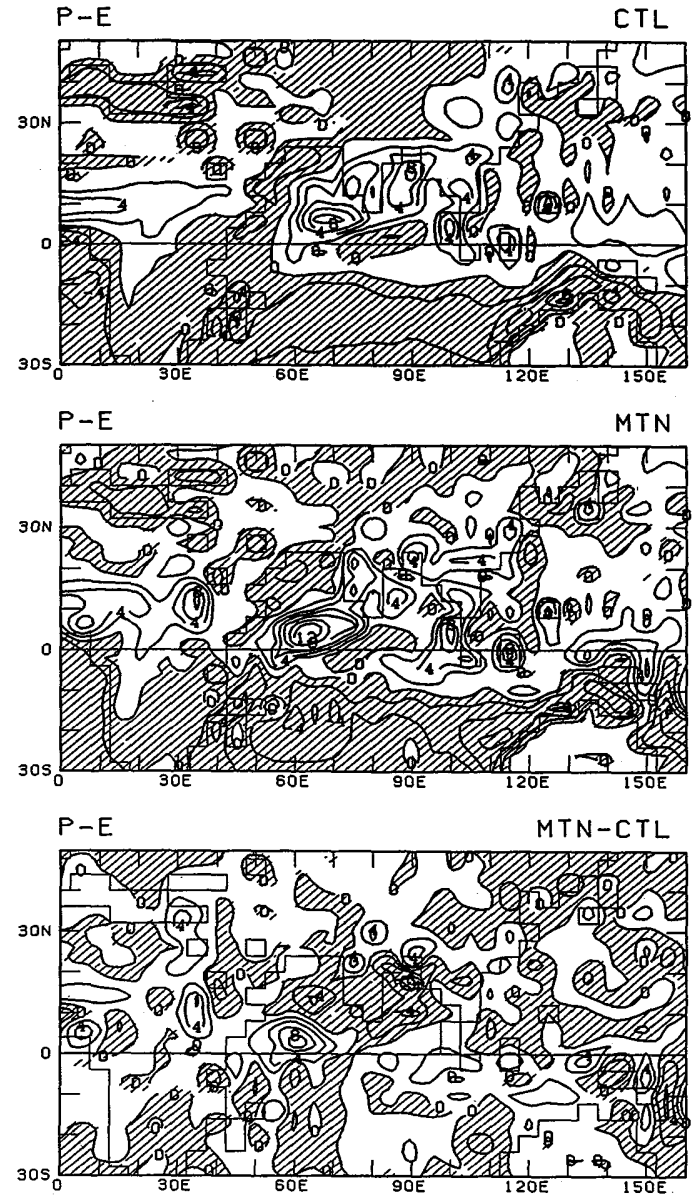

Fig. 17 Four month mean (June-September) "precipitation"--"evaporation". Top: control run. Middle: "MTN" run. Bottom: "MTN" run-control run. Contour intervals are $2 \mathrm{~mm} \mathrm{day}^{-1}$ for all panels. Negative values are hatched.

for the control run, the MTN run and their difference. Over the domain of $50^{\circ}-110^{\circ} \mathrm{E}, 0^{\circ}-30$ ${ }^{\circ} \mathrm{N}$, moisture convergence is dominant in the control run. The observed "precipitation minus evaporation" was calculated from the atmospheric moisture budget based on the NMC data (figure not shown). The simulated pattern roughly agrees with the observation, though the maximum convergence southwest of India is overestimated and the convergence at the foothills of the Himalayas is underestimated. 


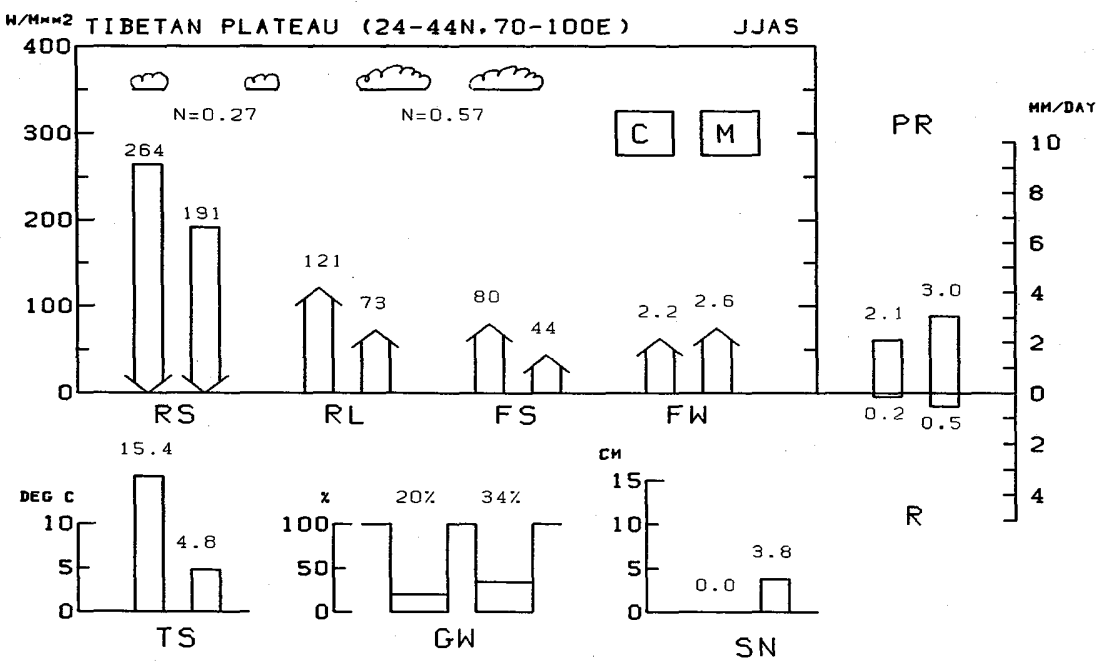

Fig. 18 Surface heat and water balance and cloudiness over the Tibetan plateau $\left(24^{\circ}-44^{\circ} \mathrm{N}, 70^{\circ}-100^{\circ} \mathrm{E}\right)$. The left (right) column of each pair represents the value in the control (MTN) run. N, cloudiness; RS, net shortwave radiation $\left(\mathrm{W} \mathrm{m}^{-2}\right) ; \mathrm{RL}$, net longwave radiation $\left(\mathrm{W} \mathrm{m}^{-2}\right)$; $\mathrm{FS}$, sensible heat flux (W $\left.\mathrm{m}^{-2}\right)$; FW, latent heat flux $\left(\mathrm{mm} \mathrm{day}^{-1}\right)$; PR, precipitation $\left(\mathrm{mm} \mathrm{day}{ }^{-1}\right) ; \mathrm{R}$, runoff $\left(\mathrm{mm} \mathrm{day}^{-1}\right)$; TS, surface air temperature $\left({ }^{\circ} \mathrm{C}\right) ; \mathrm{GW}$, ground wetness ; $\mathrm{SN}$, snow depth (cm water).

In the MTN run, the convergence increases over India and the equatorial western Indian Ocean, while it decreases over the Bay of Bengal and the Arabian Sea. However, domain averaged convergence does not change much. Therefore, despite the weakening of low-level monsoon flow, its convergence and precipitation do not change so much in a regional scale.

It is noted that a large amount of snow was present over the Himalayas throughout the monsoon season in the MTN run. This is due to the effect of the increased height of the mountain. Actually, the maximum mountain height in the control run is $4423 \mathrm{~m}$, while that in the MTN run is $5710 \mathrm{~m}$. The permanent snow in the MTN run occurs over the grid points with the elevation exceeding $5000 \mathrm{~m}$.

Over the extended Tibetan plateau region $\left(24^{\circ}-44^{\circ} \mathrm{N}, 70^{\circ}-100^{\circ} \mathrm{E}\right)$, the surface air temperature is lower by $10.6^{\circ} \mathrm{C}$ in the MTN run than in the control mainly due to higher elevation (Fig. 18). The average difference in elevation is 879 $\mathrm{m}$ over the region. Thus in addition to higher topography, the increased cloudiness contributes to enhance the cooling. Despite the cooling, the water cycle has been enhanced (Fig. 18). In the control run, the regional mean precipitation is almost balanced by the local evaporation (Figs. 17 and 18). In the MTN run, although both the precipitation and the evaporation increase, the increase in the precipitation is larger. An evaporation/convection feedback via ground wetness is working in this case (Yasunari et al., 1991). In the MTN run, the available solar energy is less than in the control. However this is more than canceled out by less longwave radiation and less sensible heat flux, and the latent heat flux is more vigorous by the above described feedback process.

It is interesting that though the large-scale features of the Asian summer monsoon circulation are deviated largely from the observation, a simulation of southerly flow at the head of the Bay of Bengal, a shift of monsoon trough slightly southwards and an enhancement/reduc- 
tion of precipitation over India/the Arabian Sea and the Bay of Bengal are closer to the observations. In short, though the large-scale monsoon flow is weakened greatly, the smallscale feature of the monsoon circulation is improved over India and its surrounding area in this MTN experiment.

\section{e. The Wet India (WET) experiment}

In the control run, ground wetness over north India becomes quite dry during summer (Fig. 19). This dryness is considered to suppress precipitation there. To examine the sensitivity on the monsoon circulation to the soil moisture over India, an experiment is performed, in which the ground of the Indian subcontinent lying in the region of $2^{\circ}-30^{\circ} \mathrm{N}, 72^{\circ}$ $-90^{\circ} \mathrm{E}$ is kept saturated throughout the integration period while the other boundary conditions are the same as in the control run.

The lower level humidity pattern shows an increase over north India through the enhancement of evaporation. This causes the increase of rainfall over central and northeast India (Fig. 20). This is an improvement compared with the control run. Such an improvement is due to the maintained wet ground over India in this experiment. On the other hand, enhanced evaporation cools the ground resulting in cold air temperature in low levels over north India. This effect works as a negative feedback to the precipitation increase (Kitoh et al., 1988).

The wind flow pattern at $850 \mathrm{hPa}$ shows a cyclonic circulation over north India, but other features are similar to those of the control run. The sea level pressure field also shows a similar pattern as in the control run but the pressure increased south of the Himalayas, i.e., in the monsoon trough region.

The $500 \mathrm{hPa}$ contour pattern shows that the height decreased over the entire area except over China and Turkey (Fig. 21). At the 200 $\mathrm{hPa}$ the northeastern part of the Tibetan high is shifted northward and intensified, while its western part over Persia is weakened. The easterly jet remained the same as in the control run. The $200 \mathrm{hPa}$ temperature distribution shows an increase over the Indian continent and Tibet probably due to the enhanced convective
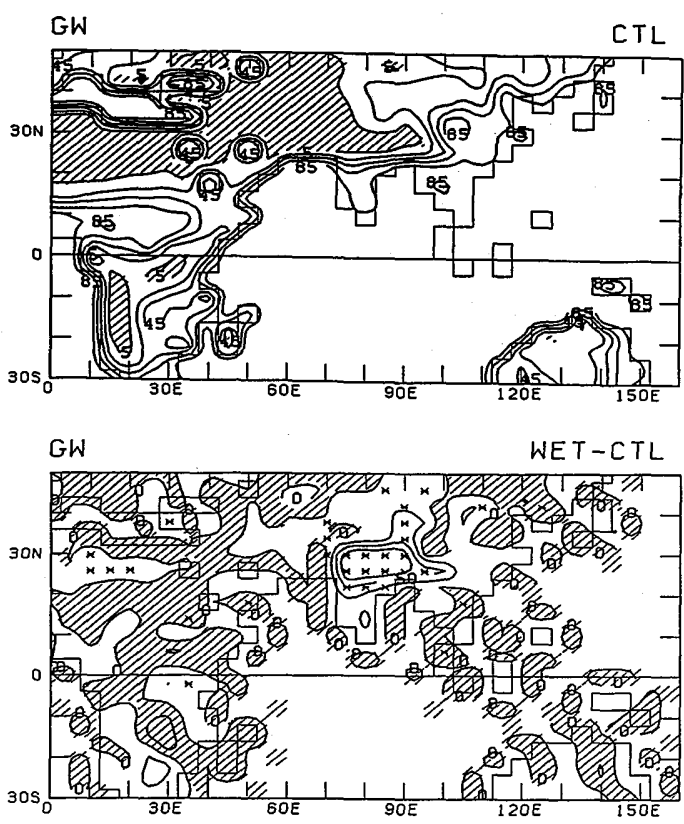

Fig. 19 Four month mean (June-September) ground wetness fields. Top : control run. Bottom: "WET" run-control run. Contour interval is $20 \%$. At the top panel, values less than $5 \%$ are hatched. At the bottom panel, negative values are hatched. Asterisk $(*)$ in the difference map indicates statistically significant points with $95 \%$ confidence level.

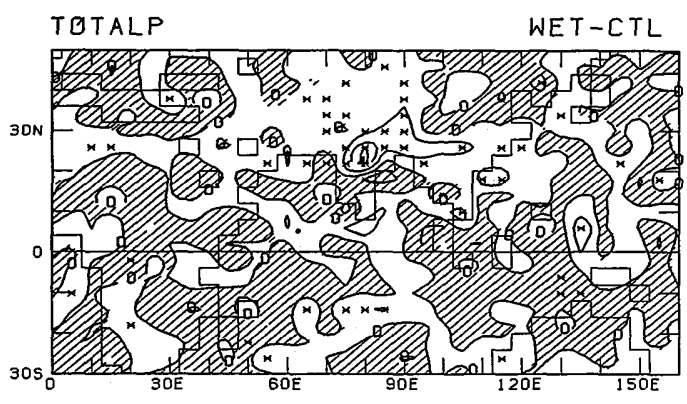

Fig. 20 Four month mean (June-September) precipitation for "WET" run-control run. Contour intervals are $2 \mathrm{~mm} \mathrm{day}^{-1}$. Negative values are hatched. Asterisk $(*)$ in the difference map indicates statistically significant points with $95 \%$ confidence level. 


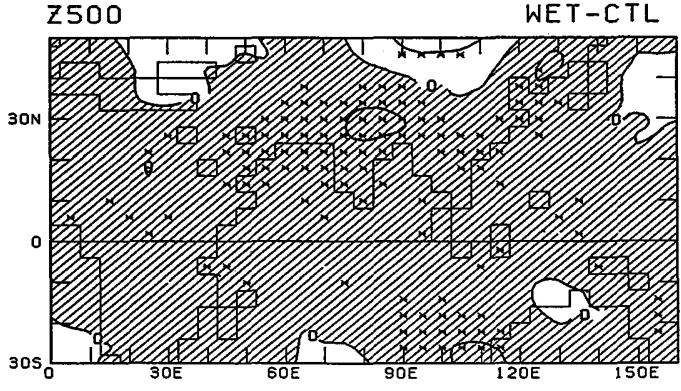

Fig. 21 Four month mean (June-September) geopotential height at $500 \mathrm{hPa}$ for "WET" run-control run. Contour intervals are $10 \mathrm{gpm}$. Negative values are hatched. Asterisk $(*)$ in the difference map indicates statistically significant points with $95 \%$ confidence level.

heating there.

Forcing ground wetness to unity seems to be artificial. It is worth examining whether initial (springtime) wet ground over India could be sustained during summer or not, because over China initially wet ground could cause the enhancement of precipitation which in turn keep the ground wet during summer (Yamazaki, 1989). To examine the existence of this positive feedback mechanism over India, an additional experiment is made, in which the ground of the Indian subcontinent in the region of $2^{\circ}-30^{\circ} \mathrm{N}, 72^{\circ}-90^{\circ} \mathrm{E}$ has been made saturated at the initial starting time and allowed to vary during the integration. The results are similar to the control run. This implies that the positive feedback of soil moisture to the rainfall is not effective here, at least within the framework of the bucket model.

\section{Summary and Discussion}

The results of a 20-year simulation by the 5-layer MRI AGCM were analyzed for the Asian monsoon region for the summer monsoon season. Overall large-scale features were simulated with considerable reality, though there were some drawbacks. The low-level westerlies over the Arabian Sea and the Bay of Bengal were underestimated in the simulation compared with the climatological flow. The monsoon trough in the low-level atmosphere shifted northward. The precipitation over the foothills of the Himalayas was underestimated, while that over the south Arabian Sea and the Bay of Bengal was overestimated. The lowlevel temperature over the Arabian peninsula was much cooler than the observation. At 500 $\mathrm{hPa}$, the trough over India shifted eastward.

Motivated by errors mentioned above, some sensitivity experiments related to land surface boundary conditions were performed. The results of the "No Persian Gulf and Red Sea (NPG) experiment" showed that the cold bias in the low-level temperature over the Arabian peninsula was alleviated by replacing 3 swamp grid points of the Persian Gulf and the Red Sea with land points, though large-scale errors were not alleviated much. The "NPG experiment demonstrates the importance of land surface treatment for regional climate.

The "High Mountain (MTN) experiment" was performed with elevated topography. The existence of high mountain ranges such as the Himalayas is considered to enhance the Asian summer monsoon circulation (Hahn and Manabe, 1975). Therefore, elevated mountains might enhance the strength of the monsoon flow. Contrary to expectation, the results of the "MTN" experiment showed much weaker monsoon circulations compared with the control run. The increased mountain barrier effects due to the elevated topography reduced the strength of the westerly flow and worked to move the mass northward and to reduce the north-south pressure gradient over the summer monsoon region. This reduced pressure gradient balanced the reduced westerlies there. Therefore, the simulated large-scale flow deviated further from the observation. Moreover, the elevated Himalayas could sustain snow throughout summer, and this cooled the lower and middle troposphere, which also contributed toward weakening the monsoon flow through the reduction of the land-ocean heat contrast. Although the present-day elevations of mountains are favorable for the enhancement of the summer monsoon compared with a flat land (Hahn and Manabe 1975), the excessively high 
mountains are unfavorable. It was shown that excessively high mountains are even harmful to an accurate Asian summer monsoon simulation. Jarraud et al. (1988) showed that an envelope orography mostly deteriorated the skill of medium-range forecast in summer using the ECMWF model. Also Slingo and Pearson (1987) showed that an envelope orography degrades the summer circulation using the British Meteorological Office GCM. The present results accord with their results. Despite these errors in large-scale features, the improvements in a regional-scale simulation were noticeable. For example, the increase/ decrease of precipitation over the India/ Arabian Sea and the Bay of Bengal and the appearance of the low-level southerly flow near the head of the Bay of Bengal are among these. This indicates that the regional features are largely influenced by regional topography such as the west Ghats and Burma mountain ranges. To improve the simulation both in large-scale and regional-scale features, a fine resolution model is desirable.

The "Wet India (WET) experiment" was performed with specified wet ground condition over the Indian subcontinent. This experiment showed some improvements over India and the surrounding regions. Nevertheless, the largescale feature has not changed significantly. Also, initially wet soil in spring over north India dried up very quickly. This experiment hints that the "bucket model" may not be appropriate over the vegetated region where there are dry and wet seasons.

The weak low-level monsoon westerlies especially over the Arabian Sea was not improved in any of experiments presented here. Neither did excessive precipitation over the south Arabian Sea. Comparing error maps of $850 \mathrm{hPa}$ wind and precipitation (Figs. 2 and 9), the errors in wind and precipitation over the Arabian Sea seem to be closely related. The excessive precipitation may have caused the error in wind. In this sense, inadequate physical parameterizations related to precipitation processes over the ocean might be the cause of these errors. This possibility should be pursued in the near future.
A fine resolution model is needed to simulate the regional features more accurately, though there is no guarantee that the fine resolution model can simulate the large-scale features more accurately (Tibaldi et al., 1990). At present, the fine resolution MRI AGCM $\left(2^{\circ}\right.$ in latitude and $2.5^{\circ}$ in longitude) is being integrated and the results will be presented in the near future.

Acknowledgments : - The present work has been carried out when the first author visited MRI under a programme of the Japanese Government Research Awards for Foreign Specialists sponsored by the Science and Technology Agency, Government of Japan. The 20-year integration (the control run) was a part of the "Japanese Experiment on Asian Monsoon (JEXAM)" supported by the Science and Technology Agency. The computations were done using the HITAC S-810/10 computer at MRI.

\section{References}

Boer, G. J., K. Arpe, M. Blackburn, M. Deque, W. L. Gates, T. L. Hart, H. Le Treut, E. Roeckner, D. A. Sheinin, I. Simmons, R. N. B. Smith, T. Tokioka, R. T. Wetherald and D. Williamson, 1991: An intercomparison of the climates simulated by 14 atmospheric general circulation models. CAS/JSC Working Group on Numerical Experimentation Report No. 15, WMO/TD-No. 425, WMO, Geneva, 37 pp.

Gates, L. W., P. R. Rowntree and Q.-C. Zeng, 1990 : Validation of climate models. In Climate Change, The IPCC Scientific Assessment, Cambridge University Press, Cambridge, $364 \mathrm{pp}$.

Gilchrist, A., 1977: The simulation of the Asian summer monsoon. Pure and Applied Geophysics., 115, 1431-1448.

Gilchrist, A., 1981: Simulation of the Asian summer monsoon by 11-layer general circulation model. Monsoon Dynamics, eds. Sir J. Lighthill and R. P. Pearce Cambridge University Press, Cambridge, 131-145.

Gill, A. E., 1980 : Some simple solutions for heatinduced tropical circulation. Q.J.R. Meteorol. Soc., 106, 447-462.

Hahn, D. G. and S. Manabe, 1975: The role of mountains in the south Asian monsoon circulation. J. Atmos. Sci., 32, 1515-1541. 
Jaeger, L., 1976 : Monatskarten des Niederschlags für die ganze Erde. Berichte des Deutschen Wetterdienstes, 18, Nr. 139, Offenbach, W. Germany, 38pp.

Jarraud, M., A. J. Simmons and M. Kanamitsu, 1988: Sensitivity of medium-range weather forecasts to the use of an envelope orography. Q. J. R. Meteorol. Soc., 114, 989-1025.

Kitoh, A. and T. Tokioka, 1986: A simulation of the tropospheric general circulation with the MRI atmospheric general circulation model. Part II : The July performance. Pap. Met. Geophys., 37, 145-168.

Kitoh, A. and T. Tokioka, 1987 : A simulation of the tropospheric general circulation with the MRI atmospheric general circulation model. Part III: The Asian summer monsoon. $J$. Meteor. Soc. Japan, 65, 167-187.

Kitoh, A., K. Yamazaki and T. Tokioka, 1988: Influence of soil moisture and surface albedo changes over the African tropical rain forest on summer climate investigated with the MRI GCM- I . J. Meteor. Soc. Japan, 66, 65-86.

Kitoh, A. and K. Yamazaki, 1991: Impact of surface drag of islands in the maritime continent on the atmospheric general circulation. $J$. Meteor. Soc. Japan, 69, 241-249.

Kitoh, A., 1991: Interannual variations in an atmospheric GCM forced by the 1970-1989 SST. Part I : Response of the tropical atmosphere. J. Meteor. Soc. Japan, 69, 251-269.

Krishnamurti, T. N., 1987: Monsoon models. Monsoons, eds. Jay S. Fein and Pamela L. Stephens, John Wiley \& Sons, Inc., 467-521.

Kuma, K., 1988: The role of the equatorial heat sources in the western Pacific ocean on the onset of the Asian summer monsoons of 1986. J. Meteor. Soc. Japan, 66, 399-417.

Shukla, J., 1975: Effect of Arabian sea-surface temperature anomaly on Indian summer monsoon: A numerical experiment with GFDL model. J. Atmos. Sci., 32, 503-511.

Slingo, A. and D. W. Pearson, 1987 : A comparison of the impact of an envelope orography and of a parametrization of orographic gravity-wave drag on model simulations. Q.J. R. Meteorol. Soc., 113, 847-870.

Sud, Y. C. and W. E. Smith, 1985 : Influence of local land-surface processes on the Indian monsoon: A numerical study. J. Climate Appl. Meteorol., 24, 1015-1036.

Tibaldi, S., T. N. Palmer, C. Brankovic and U. Cubasch, 1990: Extended-range predictions with ECMWF models: Influence of horizontal resolution on systematic error and forecast skill. Q. J. R. Meteorol. Soc., 116, 835-866.

Tokioka, T., A. Kitoh, I. Yagai and K. Yamazaki, 1985: A simulation of the tropospheric general circulation with the MRI atmospheric general circulation model. Part I : The January performance. J. Meteor. Soc. Japan, 63, 749-778.

Washington, W. M., R. M. Chervin and G. V. Rao, 1977: Effects of a variety of Indian ocean surface temperature anomaly patterns on the summer monsoon circulation: Experiments with the NCAR general circulation model. Pure and Appl. Geophys., 115, 1335-1356.

WMO, 1988: Report on the CAS/JSC Workshop on systematic errors in models of the atmosphere, WMO/TD-No. 273, 382pp.

WMO, 1990: TOGA MONSOON CLIMATE RESEARCH. Report of the Second Session of the Monsoon Numerical Experimentation Group. Kona, Hawaii, U.S. A., 26-27 July 1990. WCRP-49, WMO/TD-No. 392.

Yamazaki, K., 1988: Influence of sea surface temperature anomalies over the Indian Ocean and Pacific Ocean on the tropical atmospheric circulation-A numerical experiment- $J$. Meteor. Soc. Japan, 66, 797-806.

Yamazaki, K., 1989: A study of the impact of soil moisture and surface albedo changes on Global climate using the MRI GCM- I. J. Meteor. Soc. Japan, 67, 465-472.

Yasunari, T., A. Kitoh and T. Tokioka, 1991: Local and remote responses to excessive snowmass over Eurasia appearing in the northern spring and summer climate. - A study with the MRI GCM-. J. Meteor. Soc. Japan, 69, 473-487. 


\section{大気大循環モデルによる地表面境界条件に関する 夏季アジアモンスーンの数値実験}

ドドラ V.バスカーラオ*・山崎孝治・鬼頭昭雄

5 層の気象研究所大気大循環モデルによる 20 年間の積分結果 (コントロールラン) を夏季 (6-9 月) のアジア モンスーン領域について解析し, 観測と比較した。夏季アジアモンスーンの大規模な特徴は, モンスーンの循環 が観測より弱いなどいくつかの欠点はあるものの，概ね，良く再現されている。シミュレーションの不満足な点 に関連して，地表面境界条件に関するいくつかの数值実験を行った。コントロールランに見られたアラビア半島 の下層大気の冷えすぎは, ペルシャ湾と紅海の 3 つの沼地の格子点を陸地に代えることによって改善された。七 マラヤ山麓の雨が少なすぎた点は，インド垔大陸の土壌を強制的に湿らせると，幾分，改善された。これらの実 験はりージョナルな気候に対して，地表面過程が重要な役割を果たしていることを示している。しかしながら， 上記の実験で見られた改善はリージョナルな規模に留まっており,モンスーン全体の大規模な流れの誤差を大き く改善するものではなかった。世界中の山岳の高さを上げた実験では, リージョナルな特徴については改善が見 られたが, 大規模なモンスーン循環はかなり弱まった。余り高すぎる山岳はアジアの夏季モンスーンのシミュ レーションにとって，かえって有害であることがわかった。 